\title{
LÁGRIMAS NAS PROFUNDEZAS: ALEGORIAS UTÓPICAS EM MOBY DICK E O NOMINALISMO NA OBRA DE WILLIAM DE OCKHAM
}

Estevan de Negreiros Ketzer e Edson Luiz André de Sousa

Estevan de Negreiros

Ketzer

Psicólogo pela

Pontifícia

Universidade

Católica do

Rio Grande do

Sul (PUCRS) e

mestrando no

PPG em Letras

pela Pontifícia

Universidade

Católica do Rio

Grande do Sul

(PUCRS).

Edson Luiz André de Sousa

Psicanalista,

professor do PPG

Artes Visuais do

Instituto de Artes da

UFRGS, e professor

do Departamento

de Psicanálise e

Psicopatologia e

do PPG Psicologia

Social do Instituto de

Psicologia da UFRGS.

Pós-doutorado

em Psicanálise e

Psicopatologia pela

Universidade de

Paris VII e pela École

des hautes études

em Sciences Sociales

(EHESS), doutor

pela Universidade

de Paris VII e

coordenador, junto

com Maria Cristina

Poli, do Lappap -

UFRGS (Laboratório

de Pesquisa em

Psicanálise, Arte e

Política).
RESUMO: A obra de Herman Melville, Moby Dick, é constituída como uma utopia dentro das circunstâncias condensadas nas personagens da Baleia e do capitão Ahab. A psicanálise, em sua compreensão semântica, cuja implicação envolve o sujeito psíquico, potencializa as singularidades e o coloca ao desafio que extrapola o tempo lógico quando há um encontro na criação utópica. O nominalismo do filósofo inglês Ockham problematiza a dinâmica do conhecimento ao formular um método que corta as explicações excessivas (a navalha) e indaga qual o caminho da apropriação humana no que diz respeito ao campo da discernibilidade dos saberes, trilha esta buscada na obra de Melville.

Palavras-chave: Utopia, psicanálise, literatura, Melville, Ockham.

ABSTRACT: Cries in the deepness: utopical allegories in Moby Dick and the nominalism in the William of Ockham's work. The Herman Melville's work, Moby Dick, is a constituted utopia inside condensed circumstances in the whale and in captain Ahab figures. The psychoanalysis in its semantic understanding, in which implication involves the psychological subject, potentiates the singularity and puts it to a challenge that oversteps the logic time when there is a meeting on the utopian creation. The nominalism from the Brittan philosophy Ockham problematizes the knowledge dynamic to formulate a method that cuts the excessive explanations (the razor) and inquires what the pathway to the human ownership making sense of discern field of knowledge, this trail is being searched in the Melville's work.

Keywords: Utopia, psychoanalysis, literature, Melville, Ockham. 
“What I've dared, I've willed; and what I've willed, I'll do! They think me mad — Starbuck does, But I’m demoniac, I am madness maddened! That wild madness that's only calm to comprehend itself; and — Aye!” (Captain Ahab)

D urante a leitura de Moby Dick, de Herman Melville (1851), o leitor deparase com uma miríade de aspectos sobre o desejo do homem ao enfrentar um lugar sem nome, um desconhecimento sobre si próprio. Quais oceanos e quais profundezas de mares revoltosos? Um enorme torvelinho, descompasso, luta animal, onde as possibilidades de viver se configuram entre a paulatina presença do tempo e as declinações pessoais, cada vez mais em um profundo desapego à circunstância material, linha limítrofe e tênue. A toda hora esse lugar a ser definido, num tempo de pura espera. O autor sente-se livre para dar vida a Ishmael, narrador do livro.

“É o meu jeito de afastar a melancolia e regular a circulação. Sempre que começo a ficar rabugento; sempre que há um novembro úmido e chuvoso em minha alma; sempre que, sem querer, me vejo parado diante de agências funerárias, ou acompanhando todos os funerais que encontro (...) então percebo que é hora de ir o mais rápido possível para o mar.” (MELVILLE, 1851/2008, p.26)

Em todo o romance nos confrontamos com as tempestades de significações, e Melville, de alguma forma, indica ao leitor que nosso destino está escrito na trama dos significantes que nos constituem. Assim, podemos pensar a travessia de Ishmael como um desenrolar de um pensamento utópico que busca dar espaço e tempo, aquilo que escapa à significação, o que ainda não tem forma, o que está aprisionado na obscuridade do pensamento. A utopia que indicamos aqui segue a trilha aberta por Ernst Bloch em seu O princípio esperança, colocando em cena, sobretudo, uma dimensão do em falta, do que aciona o desejo, do que Bloch nomeia como a instância do ainda não. Trata-se de um pensamento que busca uma ação, que não foge do front da vida, ficando à espera de um tempo sonhado que nunca virá. Trata-se, para Bloch, de uma espera ativa. Sua utopia busca saber mais sobre o enigma que nos constitui. Como ele mesmo aponta no prefácio de sua trilogia:

“A consciência utópica quer enxergar bem longe, mas, no fundo, apenas para atravessar a escuridão bem próxima do instante que acabou de ser vivido, em que todo o devir (Seiende) está à deriva e oculto de si mesmo. Em outras palavras: necessitamos de um telescópio mais potente, o da consciência utópica, afiada, para atravessar o imediatismo mais imediato." (BLOCH, 1959/2005, p.23) 
Tal é a alegoria de questionamentos sobre a consistência das personagens na obra que podemos pensar a respeito da trama do autor ao retratar certas singularidades dentro do navio baleeiro Pequod. Por singularidade, queremos nos aproximar do termo proposto por John Duns Scotus (1266-1308), um filósofo escolástico que se deparou com a ecceidade (haecceity):

"Uma propriedade não qualitativa de uma substância ou coisa: isto é uma 'istidade' (uma haecceitas, do Latin haec, significa 'isto') como oposta à 'coisidade' (a quidditas, do Latin quid, significa 'coisa'). Além disso, substâncias, um tipo de metafísica defendida por Scotus, são basicamente coleções de propriedades realmente idênticas (...)” (STANFORD ENCYCLOPEDIA OF PHILOSOPHY, 2009)

Esta terminologia vai além de Scotus, tornando-se radical com o uso que seu discípulo, William de Ockham (1285-1347), realiza. As discussões teóricas do século XIV não se potencializam somente nas diásporas filosóficas, mas rumam ao sentido mesmo de nosso próprio modo de significar o mundo. Esta é uma questão que nos percorre, faz parte de nossa vida e dos encontros importantes com nossos desafios interpessoais. Logo, se a linguagem do século XIV é tão definitória em termos de precisão sobre a essência das coisas, no século XX a linguagem se esvanece de significados, fragmentando-se na tentativa de interpretar o mundo.

O que convencionamos chamar de pós-modernidade é um jogo sem fim de relações fugazes, tal como Bauman (2003) pensa. Nessas relações, o que nos parece mais verdadeiro, o pano de fundo de nosso jogo existencial, se sustenta por um período e a tentativa de tornar a dualidade de uma pergunta nivelada pela resposta do outro.

"Odo Marquard falou, não necessariamente com ironia, do parentesco etimológico entre zwei e Zweifel ('dois' e 'dúvida') e insinuou que o elo entre essas palavras vai além da simples aliteração. Onde há dois não há certeza. E quando o outro é reconhecido como um "segundo" plenamente independente, soberano - e não uma simples extensão, eco, ferramenta ou empregado trabalhando para mim, o primeiro - a incerteza é reconhecida e aceita. Ser duplo significa consentir em indeterminar o futuro." (BAUMAN, 2003, p.35)

Esse elemento da modernidade é constituído pelas tentativas de criar essa reconstrução do que somos constantemente em nossas relações. Destruir e reconstruir o outro faz parte desse jogo de relações imbricadas que a modernidade nos implica a construir ad infinitum (BAUMAN, 2003). Portanto, uma linguagem nova aparece o tempo todo para dar conta da restituição de uma cadeia signi- 
ficante. Passa a fazer parte dessa cadeia a importância do desejo e o papel que ele assume.

A narrativa de Melville leva o leitor a tal incerteza, na qual caímos em uma contradição de lógicas que justamente fazem referência ao sentido de navegar no mundo. Pequod, navio antigo, leva a tripulação em busca da grande Baleia. Da mesma forma as palavras, na tentativa de instaurarem o simbólico quando endereçadas a alguém, passam pelo processo de compreensão de sujeitos investidos de psiquismo. A metáfora com o navio ultrapassa seu sentido da caça pura e simples, dirige-se na analogia de um esquife, mortalha negra para qualquer possibilidade de mudar seu rumo. Devemos isso à obstinação do capitão da embarcação, Ahab, e à incansável correspondência interpessoal de Melville. Já no início do romance, Ishmael, ao procurar em Nantucket um alojamento, depara-se com o nome das coisas e seus presságios.

"Prosseguindo, cheguei por fim a uma espécie de luz fosca, não longe das docas. E ouvi no ar um rangido desconsolado; olhando para cima, divisei uma tabuleta balançando em cima da porta, com uma pintura branca representando, desbotadamente, um jato reto e alto de água nevoenta, e estas palavras embaixo: 'Estalagem da Baleia - Peter Coffin' (caixão). Caixão de defunto (coffin)? Baleia? Ligação singularmente ominosa, pensei eu." (MELVILLE, 1851/1972, p.33)

Melville constrói sua epopeia por meio da verídica tragédia acontecida em julho de 1821 com o baleeiro Essex, afundado por um cachalote. ${ }^{1}$ Os relatos da tripulação sobrevivente foram recontados de forma fantástica pela sociedade da época e somados à experiência de Melville com um tirânico capitão do qual foi tripulante, o Acushnet, por dezoito meses, encerrando sua viagem em 1841 ao desertar nas ilhas Marquesas. A prematura morte de seu pai quando o autor contava doze anos também serve para direcionar muitos dos encontros conflitantes das personagens na obra.

Há um elemento enigmático por toda sua escrita — sombras articuladas por trás do capitão. Afinal, quem é Ahab? A personagem aparecerá no capítulo XXVIII pelas impressões de Ishmael: "Não obstante, as velhas tradições do mar, a imemorial credulidade, atribuíram vulgarmente a esse velho de Man dons sobrenaturais de penetração." (MELVILLE, 1851/1972, p.159).

Ahab gera um delírio apaixonante sobre os baleeiros do Pequod que o seguem, determinados a enfrentar a Baleia. Entretanto, a forma pela qual o capitão se confronta com o desconhecido que o habita aparecerá no diálogo

\footnotetext{
${ }^{1}$ Para maiores referências, conferir a obra de Nathaniel Philbrick, No coração do mar (2000/2001). Rio de Janeiro, Companhia das Letras.
} 
do capítulo 132, intitulado “A sinfonia”. No diálogo entre Ahab e Starbuck, o primeiro-piloto - cuja preocupação é persuadir o capitão a desistir de caçar a Baleia - , de repente vemos o velho capitão olhar para si, extrapolando o plano daquilo que reificamos racionalmente.

"Que coisa indizível, inescrutável, sobrenatural; que falacioso, oculto senhor e amo, e cruel, desumano imperador dispõe de mim, que contra todos os afetos e anseios naturais, assim me mantenho a propelir-me, a empurrar-me, a avançar todo o tempo, temerariamente levando-me a fazer o que em meu próprio e natural coração eu não me atreveria ousar? É Ahab, Ahab? Sou eu, ó Deus, ou quem é que ergue este braço? Mas se o grande sol não se move por si próprio, mas é como um mensageiro no céu e nem um simples astro pode revolver-se, a não ser por força de algum poder invisível, como pode então este pequeno coração bater, este pequeno cérebro pensar seus pensamentos, a menos que Deus produza essa pulsação, faça esse pensamento, faça esta vida e não eu.” (MELVILLE, 1851/1972, p.632)

Aqui, a natureza tempestiva e um abrupto choque com Starbuck invadem o plano da realidade, impedindo o primeiro-piloto de mudar os rumos da história. Por alguns instantes somos surpreendidos por não sabermos do que Ahab quer se proteger - ele foge do assunto, simplesmente? Parece singularizar a questão e, ao mesmo tempo, não assume o patamar de desgraça que se apoderara dele e de sua tripulação. Starbuck fica assustado e o deixa sozinho sobre o convés. Ele reconhece que não faria o capitão retornar para Nantucket antes de matar a Baleia. Ahab está igualmente frustrado por não se permitir uma vida em terra firme - não vê a esposa e as filhas, afastado há treze anos, nos mares — sem antes questionar a validade de emoções tão pujantes surgidas em passagens muito perturbadas. Poderíamos cair com facilidade em uma interpretação empobrecida ao perguntarmos a respeito da "sanidade" de Ahab e respondermos, simplesmente, que ele "enlouqueceu" da mesma forma que Hamlet (que passa por cima da vida de seu tio para vingar seu pai, pois queria desposar sua mãe e tornar-se o Rei da Dinamarca no lugar do tio). Aqui, a figura do pai aparece como lembrança de um saber que desconhece a si próprio.

Entretanto, há um novo complexo fantasmático que surpreende o leitor de Moby Dick. Diferentemente de Hamlet, estamos diante da Baleia que surge no romance como alegoria do destino que o obceca, que o suga para uma morte anunciada, imagem também do obscuro que nos habita e que não sabemos como nomear. Quem Ahab pensa conhecer e nomear como motivo de sua desgraça e ruína precisa ser jogado para o plano da superstição, de uma representação maléfica muito presente no imaginário protestante norte-americano. Dominar o mal, projetando neste uma forma emocional de suas idiossincrasias mais con- 
flituosas, será possível apenas no diálogo com Starbuck. Vem à tona ao capitão a lágrima e rapidamente ele interpreta seus afetos como uma missão divina a ser levada a cabo. A concepção de Silva (1982) anuncia o monólogo da personagem que eclode em meio aos devaneios de uma fala livre, fluida de imagens e ideais. O fluxo de consciência compõe o eu lírico da obra, rompendo com a diegese da narrativa. Há uma desagregação da objetividade discursiva do tempo dentro da medida do narrador: este interroga seu papel. É no surgimento de um pronome pessoal na narrativa que o pensamento entra em crise. Italo Calvino enxerga essa característica do escritor Carlo Emilio Gadda como plano de tensão em suas obras: “... o eu, o eu!... o mais sórdido de todos os pronomes!... Os pronomes! São os piolhos do pensamento. Quando o pensamento tem piolhos, ele se coça como todos os que têm piolhos... e nas unhas, então... vai encontrar de novo os pronomes pessoais” (GADDA, sem data, apud CALVINO, 1990, p.124).

Reconhecemos a tensão pela tentativa desta em mostrar suas polaridades opostas e delas sermos incapazes de sair facilmente. A incapacidade de definir é a mesma que se esconde nas relações do homem com o mundo, uma postergação dos problemas metafísicos para um plano futuro. Entretanto, o desafio é latente, e em alguma dimensão ele nos atinge, fazendo-se necessário responder.

“O conhecimento (...) é a consciência da inconciliabilidade entre duas polaridades contrapostas: uma, que denomina ora exatidão, ora matemática, ora espírito puro, ou mesmo mentalidade militar, e outra que chama ora de alma, ora de irracionalidade, ora de humanidade, ora de caos" (CALVINO, p.125, 1990).

Ora, essa perspectiva é tipicamente encontrada no romance pós-moderno. Entretanto, é nesse instante que nos detemos para olhar com atenção o que a narrativa de Melville nos traz.

\section{QUERELA DE MÉTODOS: A NAVALHA DE OCKHAM PARA OS EXCESSOS DO SENTIDO}

Há uma metáfora aqui que se impõe: a construção do pensamento ocidental diante da navalha de Ockham (Ockham's razor) e o arpão de Ahab. Estruturas que possuem uma carga de verdade - entendida como termo proveniente da lógica para a verdade de uma declaração — e sentido — a noção estruturalista de relação entre termos que são compartilhados por uma organização social.

William de Ockham viveu em um momento de transformações na Europa ocidental. O século XIV e sua crise geral comportam entre outros elementos a crise interna do papado e sua mudança para Avignon, na França. Filipe, o Belo, decide cobrar imposto da Igreja em solo francês. Surgem duas grandes diver- 
gências pelo poder: 1) os dominicanos, muito próximos do filósofo São Tomás de Aquino; 2) os franciscanos, considerados os primeiros a fazer uma distinção entre religião e ciência (RUBENSTEIN, 2005).

Ockham baseou seu trabalho na capacidade da mente de construir metáforas do universo. Para o filósofo, a mente engloba a criação da realidade e sua devida análise. “(...) Ockham negava com veemência a realidade independente de entidades hipotéticas, como ‘homem’ e ‘animal'. Essas 'espécies inteligíveis’ eram meros conceitos mentais ou termos linguísticos, abstraídos pelos seres humanos dos objetos primários do conhecimento: os indivíduos realmente existentes" (RUBENSTEIN, 2003, p.212).

Ockham chama a atenção para o pensamento da perspectiva teológica reduzido a uma série de entidades para determinarem o que os sujeitos podem ou não saber. Há saberes que são concebidos como “intuitivos”, específicos de sujeitos singulares. O intelecto, nesse sentido, seria capaz de aprender certos saberes, mas, como efeito, passará a tornar tais atos do conhecimento como judicativos, ou seja, expressará um juízo acerca deles.

“As intelecções, porém, as emoções, os prazeres, as tristezas e coisas semelhantes são inteligíveis, mas de forma alguma sensíveis e algum conhecimento incomplexo dessas coisas basta para o conhecimento evidente sobre se elas existem ou não, e se existem em tal sujeito ou não; certo conhecimento delas, entretanto, não chega; (...)" (OCKHAM, 1973, p.349)

O intelecto, para reconhecer a ação de outro intelecto, necessita abstrair-se do mundo. O conhecimento passa a ser concebido como distinto de si próprio, pois pode haver uma identificação de que o objeto é diferente, ou seja, a partir da noção de conhecimento complexo (do plano do inteligível) ou o conhecimento pautado a partir da intuição, reconhecimento, que identifica um objeto com outro. O intelecto pode tornar um objeto incomplexo, ou seja, todo o termo do conhecimento que pode ser entendido como uma expressão simples ainda não é complexa de significação, precisa de complemento. Há aqui um momento de constituere intellectum distinto na especificidade de sua nomeação, que, ao tornar-se intuitivo, torna-se incomplexo de um termo ou mais. Para o filósofo, só se pode conhecer a verdade sobre uma coisa na medida em que conhecemos os fatos presentes que a geraram. Aqui surge com clareza o método, "navalha” para cortar as explicações excessivas. O excesso não pode ser entendido senão como um problema para a explicação, pois não permite que se chegue a um suficiente fim. Tal não seria o problema sobre o qual Kant se põe a debater no século XVIII acerca de um fenômeno que diz do objeto o que ele é? A mente reconhece o singular, mas não o manifesta assim: precisa associar-se à forma mais ampla encontrada, criar 
uma gestalt, instaurar uma aproximação que sugere a realidade dentro de uma dada instância - espaço e tempo - em uma circunstância intrínseca ao sujeito.

Aqui, Lacan (1955-1956/2002, p.131) aponta que “o sentido é sempre um pouco mais verdadeiro, mas é o que se tornou verdadeiro na história que conta e funciona". E se a historicidade do sujeito funciona, ele deve estar em algum lugar além de mero espectador de uma verdade transcendental. O comum do fenômeno deve ser singular e visto como ponto de interpretação do sujeito. A própria criação objetiva proposta pelo nominalismo pode ter o seu próprio valor enquanto imagem.

O trabalho com a definição de singular é considerado revolucionário se pensarmos no arcabouço teórico levado a cabo por Platão e continuado pelo grupo aristotélico. Os universais são encontrados dentro da mimese platônica na qual a tradição filosófica recai sobre as formas perfeitas e sua impossibilidade de fiel reprodução no campo da realidade inteligível. Aristóteles está inserido nessa tradição universalista, partindo dessa forma platônica de Deus ${ }^{2}$ (entendido na acepção de eternidade ou primeiro motor) recebendo as características per se unidas à substância.

\begin{abstract}
“Então dado que coisas possuem características e que algumas características pertencem a certas coisas em certos lugares e certos tempos, qualquer coisa que é uma característica, mas não de algo, pois ela é aquela coisa ou porque o tempo é agora ou o lugar é aqui, será um acidente. Isso também tem a consequência de que lá não está realmente definida a causa para o acidente, mas somente uma chance (e, portanto, indefinida) de causa." (ARISTÓTELES, 1998, p.150)³
\end{abstract}

Para Aristóteles há um problema na definição de singularidades, visto que estas sempre remetem aos acidentes, não fazem parte das essências de um determinado objeto compreendido pelo raciocínio lógico. Portanto, o que não pertence à essência não seria definível. O singular nesse ponto de vista é excluído enquanto campo de conhecimento, possibilidade de ser apreendido.

Ockham traz a discussão do universal enquanto objeto convencionado, mentalmente entendido por uma capacidade humana de abstrair as coisas reais de conceitos. Ele entende como um "ato do intelecto" uma qualidade própria da alma. “(...) essa opinião pode supor que o intelecto, apreendendo uma coisa singular, produz em si mesmo um conhecimento dessa coisa singular, apenas, conhecimento que se chama paixão da alma capaz por sua natureza de representar a coisa singular" (OCKHAM, 1973, p.359).

\footnotetext{
${ }^{2}$ Conferir o termo delegado por Albertino Pinheiro na tradução de $A$ república.

${ }^{3}$ A tradução é de nossa autoria.
} 
A antiga forma de conhecer pela representação é indicada pelo destaque da mente em criar um traço que seja próprio de suas experiências. Dessa proposta em vias de definições de conceitos, ou seja, os atos mentais são por nós entendidos como as propriedades da linguagem, que reconhecemos e retiramos de reflexões pessoais, assim como Freud (1895/1975) inquiriu da fala histérica, dando forma aos conteúdos projetados pela mente. Eis a aproximação do conceito de Ockham acerca dos universais. Os universais, na sua tentativa de generalizarem singularidades, escondem dentro de si próprios os traços do que não conseguimos exprimir por meio de palavras. Aqui, o ato excede o texto. Perguntamos então pela palavra: ela pode revelar seu sentido se compreendida em categorias a posteriori?

"Verificamos, pois nossa grande surpresa, que cada sintoma histérico individual desaparecia imediata e permanentemente quando conseguíamos evocar e despertar a emoção que a acompanhava, e quando o paciente havia descrito aquele fato com os maiores detalhes possíveis e traduzia a emoção em palavras. A lembrança sem emoção quase invariavelmente não produz nenhum resultado.” (FREUD, 1895/1975, p.47)

A palavra assume a performance do que impermanece, elucubração do que a antecede e possibilidade no que pronuncia o Real. As lágrimas de Ahab expressam o alívio imediato, escoamento do traumático pelo universal da palavra, compartilhando sua história, sobre a qual o navega(dor) não é capaz de conter a emoçã. Com ele, caem por terra os sonhos de uma vida familiar e a simples imagem de Moby Dick como um conflito necessário para seguir o rumo do Pequod para recriar o cotidiano. Talvez haja aqui o grande traço triunfal da escrita trágica, não a aniquilação de sua tripulação por um desvio insano de moral, mas antes sua arrogância que o cega com empáfia. Consideramos como hamartia a falha trágica do herói que, ao ver-se entrelaçado pela investigação de sua história, dá-se conta dos erros e entra em um processo de embate com um real que o determina.

Essa arrogância talvez seja o sinal da vida paterna de Melville como primeiro plano de um abandono existencial, constante falta em sua vida, e uma repetição em seus livros. Contudo, sua entrega à escrita, em um testemunho que fez do que viveu história e devaneio, não pode aqui ser pensado como uma espécie de questão lançada a este pai/enigma? Ahab teme de fato. Não seria este temor o que o leva a ferir a Baleia com seu arpão? Percebemos a busca desesperada de um lugar que tenta suprir uma indeterminação no sujeito. $\mathrm{O}$ arpão é a própria formação do sentido da onipotência; o devaneio é o sinthome, sempre à espera de uma enunciação possível. 
Qual laço a Baleia representa? O poder ao qual a história nos remete desvela forças antagônicas, podendo ser interpretado como um domínio das determinações do real na compulsão à repetição transbordando por sobre o sujeito, que se vê jogado contra a tempestade e o destino sem poder interromper este chamado. Ahab exerce poder e controle sobre a tripulação, tentando lidar com a angústia do deslizamento de sua razão, ligando-se ao imponderável da linguagem divina. A psicanálise propõe a narrativa de uma singularidade capturada pelas forças do Outro que a determinam.

\begin{abstract}
“Um objeto pode assumir também, com relação ao sujeito, esse valor essencial que constitui a fantasia fundamental. O próprio sujeito se reconhece ali como detido, ou, para lembrar-lhes uma noção mais familiar, fixado. Nessa função privilegiada nós o chamamos de a. É na medida em que o sujeito se identifica à fantasia fundamental que o desejo como tal assume consistência, e pode ser designado, que o desejo, também, de que se trata para nós por sua própria condição, na Höringkeit, isto é, para utilizar a nossa terminologia, que ele se coloca no sujeito como desejo do Outro, grande A." (LACAN, 1960-1961/1995, p.172)
\end{abstract}

Lacan apresenta um primeiro elo de fantasia no interior do corpo desejante. Ahab, como em um lapso, se deixa ver por dentro. Ao chorar diante de Starbuck, ele perpassa o Imaginário, extrapola seu ato de pensar sem se fixar em uma linguagem discernível para o primeiro-piloto. Vive um afeto que o amigo não consegue interpretar. Starbuck se esforça, mas está assustado. Em seguida, analisamos o dizer de Ahab “(...) Mulher! Mulher! Antes uma viúva com o marido vivo!” (MELVILLE, 1851/1972, p.631). Ele deseja o grande Outro, no auspício de reconhecer-se no psiquismo alheio, mas busca, assim, remeter àquele que também faz parte de si.

Estará selada a tragédia? Ahab lida com suas emoções para um novo modelo de intimidade via ato-dor: ele se reconhece como sujeito, aceitando seu sofrer por alguns instantes, passando a defender-se pelo devaneio da fala que eclode na figura de Deus que dele se apodera. Ockham, nesse sentido, também nos coloca diante da questão da materialidade e de uma suposta definição que se instaura no limite do pensar humano restrito pelo método da navalha.

\title{
A TRANSITIVIDADE DO SOCIAL E O ERRO DO CONCEITO
}

As personagens de Moby Dick olham para esse sentido, dito por um, mas idealizado na dialética de Deus e do diabo. Ambas as figuras se encontram na narrativa dos personagens. O Pequod é também uma metáfora do indivíduo na sociedade americana, capitalista e protestante, ávida em sua doutrina da predestinação, 
com as profecias repetidas vezes aclamadas para os eleitos de Deus, mas ainda massificada pelo culto católico (WEBER, 1920/2004).

$\mathrm{O}$ ato clínico deve resistir à universal tendência de massificar as relações, desmantelando assim a ilusão de que a razão poderia nos libertar. Conforme Adorno: "Os estilos enquanto reconhecem o guia de temas culturais de grande ressonância, deixam o caminho aberto, em seu caráter geral, precisamente a essas mitigações desnaturalizadas que impedem a coerência da ideia não programática, imanente à própria coisa" (2004, p.14).

Se essa modernidade é capaz de mitigar mais ainda os caminhos da razão, mesmo ao decidir conhecer a si própria, também quer dar conta de um inconsciente, uma instância para tudo que não havia sido compreendido pela razão.

Em Nietzsche, esse deus é desterritorializado, criatura postergada para o Imaginário, devir em que, assim como o homem é "uma corda sobre um abismo” (1970, p.25), passagem de uma jornada. Ishmael, diferentemente de Ahab, percebe a grandeza de Quiqueg. O sentimento de união sobre o catre é dividido entre os dois como um amparo ao mundo da "benevolência oca" (MELVILLE, 1851/1972. p.80) da cristandade. É por meio de um significado compartilhado entre os dois que o dito selvagem se humaniza aos olhos de Ishmael.

Pierre Clastres compreende um liame no qual o lado obscuro ininteligível de certas comunidades Tupi-Guarani brasileiras delega à figura do xamã para habitar uma comunicação com instâncias imponderáveis da mata. A sociedade primitiva transmite seu temor e o integra ao xamã, ligando o desconhecido ao cotidiano inteligível da sociedade. "Ao transformar o psicopata em médico, a sociedade o integraria a si beneficiando-se de seus 'dons' e bloquearia desse modo o desenvolvimento provável de sua psicose: o xamã não seria mais o médico da tribo, mas, em suma, um grande doente cuidado por sua sociedade" (CLASTRES, 2004, p.109).

É neste momento que o cuidado, a escuta ao outro, torna-se mais forte na sociedade indígena do que a adaptação do outro na sociedade ocidental.

A proporção desse empreendimento nota-se pelo destaque que a personagem do Padre Mapple antevê sobre aquele que desrespeita os desígnios de Deus, numa analogia à história de Jonas e a Baleia. "Não vedes, pois, companheiros, que Jonas procurava fugir de Deus até o extremo do mundo? Miserável! Oh! Desprezibilíssimo e merecedor de todo o desdém! Com chapéu desabado e olhar cheio de culpa, a fugir de Deus; espreitando entre os embarques, como um vil assaltante aflito por cruzar os mares" (MELVILLE, 1851/1972, p.70).

A personagem de Jonas é descrente de Deus, ao contrário de Ahab, que crê na divindade e permite que esta se apodere de seu ser, miticamente. Verifica-se uma típica compulsão a certos atos que não são mais que fatos marcantes na tragédia. Não importa tanto o convencimento da tripulação em aceitar a per- 
seguição à Baleia, mas o que, desse conflito, recai sobre um ponto singular de convergência, e da possibilidade de Ahab recriar o sentido dentro da repetição de seus pensamentos, sempre circulares. Parece que é sempre na palavra e em suas sutilezas que o devir esmorece; no entanto, torna-se forte diante de sua fraqueza, no esforço de representar o mundo vivido. A escrita trágica também segue consolidada por uma degeneração, um suposto declínio que se configura a partir de uma vivência de si mesmo, um primitivismo dionisíaco. E nisto somos conduzidos a pensar que certa falta de apego nos conduza à resignação.

Ao despertar para a emoção e dar vista a esta, Ahab pode rever seus valores, desejar e regozijar-se como construtor de uma possibilidade até o inusitado. Aquilo que foi encoberto deve retornar, como descrito pelo conceito freudiano Wo Es war soll Ich werden. ${ }^{4}$ Isto inclui a passagem por estágios fracionados desse desejo esquecido, visando uma necessidade de nomeação, tão esperada na personagem de Ahab. O capitão se debate sobre o ser e não ser ele mesmo, problema da modernidade e suas aporias subjetivas.

As lágrimas de Ahab tomam forma, emergem da esfera das defesas, tornase enfadonho levar a cabo sua angústia. "Starbuck viu o velho; viu como ele se apoiava pesadamente na amurada, e pareceu ouvir, em seu próprio e honesto coração, o desmedido soluço que parecia sair furtivamente do centro daquela serenidade em redor." (MELVILLE, 1851/1972, p.630). Aqui poderíamos evocar novamente um pensamento da utopia como fracasso de todo sentido, como aposta em novas significações que ainda não puderam ser nem sequer imaginadas pela mente de um intérprete, se não pela tentativa metafórica com o mundo.

Em que se torna mais verdadeiro interpretar Ahab diante de um momento trágico? Ele continua seu caminho mergulhando uma parte de si na Baleia e expurgando a dor aparente pela via sintomática. Com sua lágrima, há um retorno ao problema das coisas fixas e nominalmente universais. Se, em Ockham, o conceito-chave é a definição, e a explicação suficiente para o conceito pela via da objetividade, em Ahab essa definição lhe escapa por entre pensamentos

\footnotetext{
4 “Onde havia o Isso, o Eu deve advir". Não podemos deixar de pensar no paralelo existente aqui com a dialética hegeliana do Senhor e Escravo em que a consciência depara-se com a noção de "identidade eu = eu, que tem como oposto o ser-refletido (...)." (LUFT, 1995, p.50). Há aqui o rompimento da articulação sujeito - objeto de que a consciência deseja mostrar a si mesma quem é, indo em busca da totalidade do mundo na relação com o outro. Está incutido nessa relação um retorno sobre si mesmo e uma exteriorização do mundo na busca de uma universalidade desta mesma relação. A noção de universal, como já vimos, está em um patamar de diferença ao singular. Na obra, Ahab crê na dependência de sua tripulação, pois é colocado no lugar de ostentação e dominador. Deduz-se de Hegel: aquele que veio depois (Ahab) é anterior (imagem de Ahab), é percepto do imaginário a ser revelado, parte singular da relação (Beziehung).
} 
conflitantes, porque cindidos numa imaginação confabulatória. Seu passado condena-lhe a aceitação da derrota no presente e não é senão marca da própria tragédia: o Eu recrudesce, apropriando-se de um sentido moral e delimitando suas fronteiras, simplesmente no enigma do Eu transcendente. Responde ao desejo e a um novo movimento de esquecimento. Assim, Ahab é obrigado a fugir para a divinização. Não está louco, mas seu sofrer é insuportável, precisa colocar-se na posição de Capitão, com todo o discurso de sua tripulação sobre sua figura inefável.

Dessa forma, Ahab, ao ferir a Baleia, entregando-se ao devaneio, não partilha de um sentido imposto à realidade, mas entrega-se ao pathos, comunicante a uma Verwerfung freudiana (princípio de foraclusão, mais tarde trabalhado por Lacan). Seria então o diferente entendido como hostil? Habita a inconformidade do ser, pretensamente invadido pelo Outro. O pathos não é natural da palavra virada em vento da alma, é uma alameda do ato de criar e instaurar algo novo. Matar como única medida e criar assim a marca de singularidade. Seria essa a marca da tragédia? O devaneio tomado em seu sentido pessimista acerca de si? Muito mais próxima é a marca poética de Melville.

“Em direção a ti eu rolo, a ti, baleia, que tudo destróis, mas que nada conquistas; até o fim eu luto contigo; do coração do inferno eu te firo; do puro ódio cuspo em ti meu último alento. Afunda todos os caixões e todos os ataúdes numa só poça! E uma vez que nenhum poderá ser meu, deixa-me então ser rebocado em pedaços, enquanto ainda te persigo, embora atado a ti, a ti, maldita baleia!” (MELVILLE, 1851/1972, p.666)

Nesta passagem, há uma tentativa de destruir com profundidade a superfície do corpo. O arpão, muito próximo à navalha de Ockham, corta, dilacera, na esperança de que com isso possa definir a presença do tempo na personagem de Ahab. O capitão quer definir para si o que ele é, perfurando o indizível, sem desconfiar que o nome já faz parte dele, e é Moby Dick. Acaba por perfurar uma parte de si, possibilidade inaudita à busca do significante. O singular disso tudo é a noção de enigma que a Baleia coloca. Ela não é um nome que ele tenha em si senão por uma fantasia. Ahab tenta exprimir desse nome sua essência, precisa de uma explicação que lhe seja suficiente para crer na veracidade de sua construção discursiva que legitima a ação apaixonada contra a Baleia. Esse nome, psicanalítico e concomitante às relações mais complexas da carne, que é a projeção do próprio afeto, não é encarado como realidade motora e fluida de Ahab. O capitão precisa romper o laço social, precursor de um sofrimento por ele desconhecido, ainda mitigado sobre seu corpo fracionado pelo desejo. Essa superfície precisa ser 
antes sexualizada, investida de um ser desejante de saber sobre si, de impor sua existência à essência. Somente o outro, ente investido de nossos ideais primevos, vistos sob a égide de uma imagem invertida e, ao mesmo tempo, formadora desse princípio de ser, pode dizer algo sobre si.

As definições de Ockham, quando tenta cortar os excessos e, assim, cortar o que se agrega a todo ente — nesse caso, sujeito — , da mesma forma que Ahab decide cortar uma parte de si que o assusta e que lhe é insuportável, mostra um aparato religioso que destitui a alegria como um fazer e a busca de Ahab pelo conhecer-se a si na luta com a ponta afiada de um arpão. É a própria realidade superior à realização de uma operação destrutiva. Entretanto, não será esse enfrentamento de sua fraqueza algo admirável em Ahab? Consciente de que viver é perigoso, mesmo assim segue seu destino.

Ahab é rígido em sua crença, está imbuído de um sofrimento latente e repetitivo sobre si. O sintoma esmiúça a forma de lidar com as sutilezas do espaço e do tempo dentro do corpo, são vicissitudes. A todo momento, Melville nos brinda com o impacto de sua literatura utópica, pois o capitão é capaz de sinalizar o sintoma, como desvendamento na cadeia de significantes que irrompe de modo repentino sobre as estruturas aparentemente bem fixadas.

O pensamento entra em colapso diante da superfície e do que ela reverbera (theoría) nas paredes do que está dentro de si em vias de se tornar uma alternativa para desabrochar o novo. É neste ponto que a utopia revela a chance de aparição de um significante novo. Ahab está muito próximo disso, mas Starbuck não se sensibiliza, pois diz a ele o que fazer com seu destino (moira). A tragédia é novamente o imponderável que já vivenciamos e que buscamos definir no campo do Real, inalcançável pela unicidade humana. Está esquecida em alguma parcela de nós, necessariamente constituinte de um espaço sem nome. Ahab é uma partícula dentro de si. Marca o fenômeno da angústia, não mais como um castrador de sua dependência ao mar, mas agora vista no indecifrável, na diversidade de quem ele é e na busca delimitadora incessante.

Com o naufrágio, nosso narrador encara o desfecho dentro de si com a citação de Jó: E só eu escapei para contar a ti, tal a unicidade de todos os elos interrompidos e no que foi inaudito pelas dúvidas anteriores. Mas ainda vale pensar numa transliteração do significante, pois Melville provoca uma impressionante inversão lógica: o barco se torna esquife, e o pequeno esquife - preparado por Queequeg, amigo de Ishmael que constrói sua pequena embarcação-túmulo durante a viagem, quando cai doente — se torna barco. É o esquife do amigo que, ao passar ao lado de Ishmael, lhe dá a chance de sobreviver, preservando a vida de um, para que o mundo possa saber so- 
bre o destino do Pequod e seus marinheiros. Resta somente a escrita e seu arquipélago subjetivo. Ishmael é órfão, como Ahab, pois também navega sua história com a graça de sua introspecção. É um imponderável diante da realização interna na vontade de descrever novamente o naufrágio desse baleeiro Essex, sem pai, na calmaria do mar suave de elegia fúnebre. Segue como final o resgate e a condição interna de reparação da realidade psíquica pela via da narrativa, cujo desenvolvimento é de autoria de Melville, com seus conflitos e esperanças.

Recebido em 26/1/2009. Aprovado em 17/6/2010.

\section{REFERÊNCIAS}

ADORNO, T. W. (2004) Filosofia da nova música. São Paulo: Perspectiva. ARISTOTLE. (1998) The methaphysics. London: Penguin Books.

BAUMAN, Zygmunt. (2003) Amor líquido: sobre a fragilidade dos laços humanos. Rio de Janeiro: Jorge Zahar.

BLOCH, E. (1959/2005-2006) O princípio esperança, v. I (Tradução de Nélio Schneider) Rio de Janeiro: Contraponto/Eduerj.

CALVINO, Italo. (1990) Seis propostas para o próximo milênio: lições americanas. Rio de Janeiro: Companhia das Letras.

CLASTRES, P.(1980/2004) Arqueologia da violência. São Paulo: Cosac \& Naify.

FREUD, S., BREUER, J. (1974) Edição standard brasileira das obras completas de Sigmund Freud. Rio de Janeiro: Imago.

(1893-1895) "Estudos sobre a histeria". v. 2, p.43-363.

LACAN, J. (1955-1956/2002) O seminário, livro 3: As psicoses. Rio de Janeiro: Jorge Zahar.

. (1960-1961/1995) O seminário, livro 8: A transferência. Rio de Janeiro: Jorge Zahar.

LUFT, E. (1995) Para uma crítica interna ao sistema de Hegel. Porto Alegre: Edipucrs.

MELVILLE, H. (1851/1972) Moby Dick: ou a baleia. São Paulo: Abril Cultural.

(1851/2008) Moby Dick. São Paulo: Cosac Naify.

NIETZSCHE, F. (2007) O nascimento da tragédia: ou helenismo e pessimismo. São Paulo: Companhia das Letras.

OCKHAM, W. of. (1973) "Problemas Epistemológicos", in Os pensadores. São Paulo: Editora Abril.

PLATÃO. (1952). A república. Tradução de Albertino Pinheiro. São Paulo: Athena. 
RUBENSTEIN, A. (2005) Herdeiros de Aristóteles: como cristãos, muçulmanos e judeus redescobriram o saber da antiguidade e iluminaram a Idade Média. Rio de Janeiro: Rocco.

SILVA, V. M. de A. (1982) Teoria da literatura. Coimbra: Livraria Almedina.

STANFORD ENCYCLOPEDIA OF PHILOSOPHY. Medieval theories of Haecceity. Stanford [2009]. Disponível em: http://plato.stanford.edu/about. html. Acesso em: 25/5/2010.

Estevan de Negreiros Ketzer

estevanketzer@ibest.com.br

Edson Luiz André de Sousa

edsonlasousa@uol.com.br 